\title{
Immigration Control On Foreign Visiting Permit In South East Sulawesi
}

\author{
Rizki Putri Meilinda \\ Program Studi Magister Kenotariatan Fakultas Hukum Universitas Hasanuddin \\ Jln. Perintis Kemerdekaan Km. 12, Makassar, Sulawesi Selatan, Indonesia. \\ E-mail:pu3_meilinda@yahoo.co.id \\ Abdul Razak \\ Program Studi Magister Kenotariatan Fakultas Hukum Universitas Hasanuddin \\ Jln. Perintis Kemerdekaan Km. 12, Makassar, Sulawesi Selatan, Indonesia. \\ E-mail: Abdulrazak@yahoo.com \\ Zulkifli Aspan \\ Program Studi Magister Kenotariatan Fakultas Hukum Universitas Hasanuddin \\ Jln. Perintis Kemerdekaan Km. 12, Makassar, Sulawesi Selatan, Indonesia. \\ E-mail: Zulkifliaspan@gmail.com
}

\begin{abstract}
This study aims to find out and explain the immigration control system on foreign residency permits conducted by the First Class Immigration Office of Kendari City as well as to find out and explain the immigration control on the abuses of visitor visas by foreigners in Southeast Sulawesi. Type of this research is empirical sociological research by collecting data, examining primary data in the form of interviews. The secondary data that is available in the field, examins the existing facts, in line with the observations made in the field and then reviewed based on relevant legislation to solve the problems. Data obtained from the results of both primary and secondary data were analyzed qualitatively using theoretical basis then presented in a descriptive. The results of this study indicate that the immigration control system on foreign residency permits conducted by the Immigration Office Class I Kendari City there are 2 (two) types of administrative supervision and field supervision. Administrative control is done by checking the validity of immigration documents in the form of travel documents or sponsorship and visit permits and by the immigration. while field supervision is supervised by direct disbursement to any company that has a foreign worker and monitors the sponsor or company on the validity of the residence permit including open supervision and closed supervision, and Immigration Control on the abuses of visa visits by foreigners in Southeast Sulawesi can be done by way of prevention prior to the occurrence of a law violation in the form of periodic observation / surveillance, disguise and acting as intelligence as well as supervision is done in the form of countermeasures in this case the visit visa abuse by following up and processing legally and deporting for foreigners who proven to abuse visa Southeast Sulawesi.
\end{abstract}

Keywords: Immigration, control, residence, permit.

\section{INTRODUCTION}

Law is an instrument of society order therefore it has to be in line with the society's dinamics. Sometime, Law is made for the need of society's future development, as Roscoe 
Pound said that "Law as a tool of social engineering". The above phrase often interpreted as "Law is a society development instrument". ${ }^{1}$ The existence of foreign labor in Indonesia as capital and manpower investor in order to implement transfer of knowledge and transfer of know how, the need of professional expert and technologies to support working process made private companies hires foreign labors.

To regulate the traffic of foreign labor in Indonesia's territory, Government immigration policy is embraced the principle of selective policy namely a policy based on selective principle. According to this principle, obly those foreigner who contributes to public and state of the republic of Indonesia welfare who disharm the security and order and do not hostile toward people neither the state of the Republic of Indonesia allowed to enter or leave Indonesia's territory based on Pancasila and Constitution of the Republic of Indonesia 1945 known as UUD NRI 1945. To that extend it is necessary to form regulation and limitation for foreigner to stay in Indonesia. ${ }^{2}$

Foreigner who intend to enter and stay in Indonesia regulated under Law of entering and leaving Indonesia's territory, travel document of the Republic of Indonesia, visa, entering mark, stay permission, immigration supervision, immigration administrative action and investigation. It means that somebody or any party is forbidden unless allowed by Government. Thus, Government tied its role in any action of one of related party. ${ }^{3}$ Global situation nowadays, promotes the increase of world's citizen mobility that evoked various impacts, either advantageous or disadvantage the interest and life of Indonesia. Therefore, it requires Laws to provide immigration legal certainty namely Law number 6 of 2011 concerning immigration known as immigration Law as ammandment of Law number 9 of 1992 concerning immigration.

According to Article 1 number 1 immigration Law, immigration is the matter of people's traffic entering or leaving Indonesia's territory and its supervision in order to preserve the state's sovereignty. Immigration Law in someways correcting and re-regulate some former regulation that is against the values of human rights. For example, it provides protection for human smuggling and trafficking victim, detention time periodand the rights

\footnotetext{
${ }^{1}$ Tumpa, H. A. (2015), 'Penerapan Konsep Rechtsvinding dan Rechtsschepping oleh Hakim dalam Memutus Suatu Perkara', Hasanuddin Law Review, vol. 1, no.2, p. 126 - 138.

${ }^{2}$ Indra, M. (2008), Perspektif Penegakan Hukum dalam Sistem Hukum Keimigrasian Indonesia, Disertasi, Program Doktor Pasca Sarjana Universitas Padjadjaran, Bandung.

${ }^{3}$ Pudyatmoko, Y. S. (2009), Problem dan Upaya Pembenahan, Jakarta: Grasindo,
} 
for job for certain foreigner in Indonesia. ${ }^{4}$ Immigration Law stressed out various aspects of human rights, economic development facilitator and transnational organized crime. In the field of human right, every single Indonesian citizen entitled a mutual right to enter and leave Indonesia and no deterrence is applied for Indonesian citizen. In the field of economic development facilitator, immigration Law provides facilities and convenience for investors to obtain living permit in Indonesia. In the field of transnational organized crime, immigration plays an important role to prevent transnational crime such as people's smuggling and trafficking and drugs abuse committed by transnational syndicate. Immigration policy that formerly in the form of selective policy evolves to be "selective policy that uphold human rights". 5

According to Article 1 Paragraph 18 Immigration Law regulates that visa of the Republic of Indonesia, furtherly called as visa is a written statement given by authorized official in the representative of Republic of Indonesia or other location allowed by the government of the Republic of Indonesia which contain permission for foreigner to travel to Indonesia's territory and the basis to establish stay permit. ${ }^{6}$

Sufficient knowledge of immigration law enforcement process is very important since the determination of a violation case settled under criminal law or administrative law process which positioned as the authority of immigration officer. Therefore, necesarrily to make a strict limitation and categorization in the law enforcement process to be taken, either criminal law or administrative law action. Thereby, it no longer depends on the judgement of immigration officer but system or law based by considering a quick, effective and efficient immigration dispute settlement process. ${ }^{7}$ Technically, in field, the immigration corps is front liner of law enforcement toward foreigner illegal entering without distinguished their status either an asylum seeker, refugee or other against immigration law. ${ }^{8}$

Aim of this immigration act is to conduct supervision and to assist the implementation preventive or repressive law enforcement in the Indonesia's territory, particularly in the west Sulawesi region. Legal issue of the research is the increase of violation against immigration law every year. The above situation shows the existence of immigration law enforcement

\footnotetext{
${ }^{4}$ Dewansyah, B. (2015), 'Perkembangan Politik Hukum dan Kebutuhan Hukum Keimigrasian Indonesia: Menjawab Sebagian, Melupakan Selebihnya', Hasanuddin Law Review, vol. 1, no.2, p. 140 - 162.

${ }^{5}$ Hamidi, J. \& Chritian C. (2015), Hukum Keimigrasian, Jakarta: Sinar Grafika, p. 9.

${ }^{6}$ Sihombing, S. (2013), Hukum Keimigrasian, Bandung: Nuansa Aulia, p. 40.

${ }^{7}$ Indra, M. (2008). Opcit. p. 16.

${ }^{8}$ Sutanto, H. (2017), 'Penegakan Peraturan Keimigasian Dalam Mencegah Masuknya Imigran Illegal ke Indonesia', Jurnal Revormasi Hukum, vol. 1, no.1, p. 143 - 152.
} 
weakness, particularly related to supervision foreigner who enter and leave Indonesia. Hence, writer identified immigration supervision system toward foreigner staying permit conduct by immigration office class 1 , city of Kendari and immigration supervision toward foreigner's missuse of visiting visa in southeast Sulawesi. The above background, lead writer to formulate these research questions:

1. What is the immigration staying permit supervision system applied by immigration office class I of Kendari city?

2. How is the immigration supervision system toward missuse of visiting visa by foreigner in southeast Sulawesi?

This research is a sosiologic-empiric legal research which conducted to collect and gain primary data or in-field data and analyzing existing facts in line with in-filed supervision to be further confirm with related regulations, since laws are made and established by the member of the society. ${ }^{9}$

Populations of this research are the immigration office class I of Kendari city, labor and transmigration office of southeast Sulawesi province, police department of southeast Sulawesi and companies in the city of Kendari. From above populations writer summarizing samples as follows:

1. Head of supervision sub section of immigration office class I city of Kendari city, 1 person;

2. Head of supervision and enforcement section of immigration office class I of Kendari city, 1 person;

3. Head of labor supervision coaching and work healthy and safety unit of labor and transmigration office of southeast Sulawesi province, 1 person;

4. Head of sub directorate intelligence IV Southeash Sulawesi police department, 1 person;

5. Labor of selected companies, 5 persons.

Type and data sources of this research are as follows:

1. Primary data consist of data that is legally forceable directly collected from society due to observation and sighting. Primary data used in this research consist of relevant and related regulations with the research.

\footnotetext{
${ }^{9}$ Soemitro, R. H. (2010), Dalam bukunya Mukti Fajar dan Yulianto Achmad. Dualisme penelitian hukum (normative dan Empiris), Yogyakarta: Pustaka Pelajar, p. 154.
} 
2. Secondary data are providing description on primary data, hereby secondary data referred to visa.

Data collection technic of the research is conducted by interviewing informant and respondent also library research. Entire data, whether primary or secondary data are processed and analyzed qualitatively to be descripted in order to provide understanding through illustrating, describing and explaining conclution of the research.

\section{ANALYSIS AND DISCUSSION}

\section{A. Immigration supervision system toward foreigner's living permit conducted by immigration office class I, city of Kendari}

Supervision is an activity striving to achieve organization's goal. As there is a deviation, such activities have to make sure what deviation is and what action needed to overcome it. Supervision (controlling) is a vital management function within an organization, any other function will not be effective without supervision function.

Related to the above description, foreigner labors' living permit supervision aimed to make sure that there is no immigration Law violation committed by foreign labors. Without supervision from immigration office class I Kendari city will raises the possibility of regional and local labors loss in southeast Sulawesi. Supervision object of immigration office class I of Kendari city is including the area of southeast Sulawesi, namely city of Kendari, district of Konawe, district of north Konawe, district of south Konawe, district of Kolaka, district of west Kolaka and district of Bombana.

According to interview with Haerul Ikrar Rusli ${ }^{10}$ writer find out that the supervision on foreign labors conducted by immigration office class I city of Kendari city consist of 2 (two) types. First supervision is administration whereas second supervision is in-field supervision. In-field supervision divided into open and close supervision.

Administration supervision of the immigration office is conducted by checking the immigration document legal status which in the form of travel paper or sponsor and visiting permit. In this supervision, the immigration office will have to conduct cross check with the companies (sponsor) of foreign labors in order to establish immigration permit. This meant to maintain the data validity.

\footnotetext{
${ }^{10}$ Kepala Sub Seksi Pengawasan Kantor Imigrasi Kelas I Kendari Provinsi Sulawesi Tenggara, wawancara dilakukan pada tanggal 22 Juni 2017.
} 
Standar operational of administration supervision is as follows ${ }^{11}$ :

1. Officer collecting information through:

a. SIMKIM (Immigration Information Management System)

b. Report of immigration intelligent investigation

c. Public report/complaint

d. Offline / electronic/ social media

e. Related institution

2. Directorof WASDAKIM/KAKANIM solicit KASUBDIT/ KABID/ KASI/ KASUBSI to organize meeting of the preparation of immigration supervision to conclude:
a. Amount of personal
b. Communication device
c. Transportation device
d. Budgeting
e. Warrant of time period
f. Supervision due date
g. Safe house

3. Director of WASDAKIM/KAKANIM establish SPRINT (warrant) including:
a. Officer identity
b. Target time period
c. Target
d. Duties
e. Budgeting

In-field supervision is a supervision conducted by investigating every company which hires foreign labors. Particularly by monitoring the sponsor or company related to valid date of living permit in order to find out the existence of immigration violation. Such supervision is categorized as open supervisor which mean the supervision conducted by visiting particular location, showing the officer identity and warrant of foreign labor supervision. On the other hand, close supervision conducted by indisguising in the suspected spot. This meant to arrest and investigates the foreign labors.

\footnotetext{
${ }^{11}$ Hasan, A. (2015), 'Pengawasan Dan Penindakan Keimigrasian bagi orang asing Yang melebihi batas waktu izin tinggal di Indonesia', Jurnal Hukum Lex et Societatis, vol. 1, no.1, p. 5 - 13.
} 
Standard operational of immigration in-field supervision is as follows:

1. Supervision by officer
a. Shows letter of warrant and officer identity
b. Checking foreigner existence
c. Asking the foreigner to show their immigration document
d. Match the identity in the immigration document
e. Conduct interview and checking the conformity of foreigner's activities with their living permit and the officer filled immigration interview result form.

2. Officer composed immigration supervision operational report. The supervision includes various kind of foreigner's violation such as overstay and visa violation. Therefore, supervision toward foreigners are equal, both administrative and infield.

Further, he explains that according assignment letter establish by ministry of Law and Human Rights of the Republic of Indonesia No. W25.IMI.1-GR.02.01-1002. its letter stated that the involving parties on the supervision of foreigners who works in the Indonesia's teritorrry, in this matter named TIM PORA (Foreigner's Supervision Team). This team is a government institution consist of Labor office of the southeast Sulawesi province, Police Department of southeast Sulawesi, immigration office class I of Kendari city and Indonesia National Army (TNI) which named BAIS (Strategic Intelligent Body) for this occasion.

He underlined that the anticipation step to held an effective supervision process, his institution form monthly meeting by collecting reports from supervision team, either written and direct report. From each data, we can find out number of living permit violation, if the number is high, we will arrange tighter supervision and arrange more intensive socialization or establish warning for the company or foreign worker.

According to interview with Magner Sinaga ${ }^{12}$, he explains that a supervision supposed to conducted toward companies who hires foreign labors as we worried to the emerge violation, particularly related to their validity and legality. Problem of the research related to living permit misused to work as the foreigner only hold visiting permit. Therefore requires maximum supervision to prevent the loss of local government.

He further explain that the immigration office class I of Kendari city is the authorized institution to establish working permit for foreign labor and also conduct supervision toward

\footnotetext{
${ }^{12}$ Kepala Bidang Pembinaan Pengawasan Ketenagakerjaan dan Keselamatan serta Kesehatan Kerja Dinas Ketenagakerjaan dan Transmigrasi Provinsi Sulawesi Tenggara, wawancara dilakukan pada tanggal 13 Juni 2017.
} 
companies in the area of south east Sulawesi. Supervision by immigration office of Kendari city toward each company meant to reach targeting goals and objective.

Tables bellow providing information of migrant workers in southeast Sulawesi and list of companies hiring migrant workers in southeast Sulawesi based on document of Labor and Transmigration office of Souheast Sulawesi province.

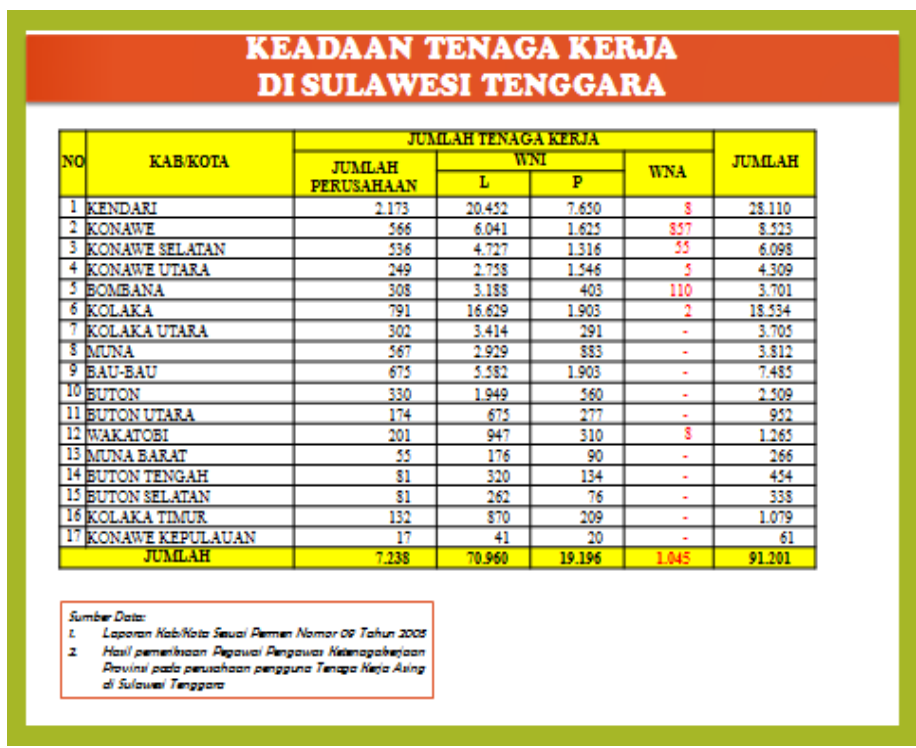

\begin{tabular}{|c|c|c|c|}
\hline \multicolumn{4}{|c|}{$\begin{array}{l}\text { PERUSAHAAN PENGGUNA TENAGA KERJA ASING } \\
\text { DISULAWXITENGGARA }\end{array}$} \\
\hline \begin{tabular}{|l|l|}
$N_{0}$ & Kab/Kota \\
\end{tabular} & Nama Perusabaau & Jumlah TK. & Asal Negara \\
\hline \multirow[t]{2}{*}{\begin{tabular}{|l|l|}
1 & Konawe \\
\end{tabular}} & 1. PT.VDNI & 856 & China \\
\hline & 2. PT. Sinar JayaUtamaSultra & 1 & China \\
\hline 2 Kolaka & 1. PT.Mapan Asri Sejahtera & 2 & China \\
\hline \multirow[t]{4}{*}{3 Kendari } & 1. PT.SonokLestarimas & 5 & China \\
\hline & 2. PT.Kumming Gold Fortune & 1 & Singapura \\
\hline & 3. PT. Fajar Phinisi Seased & 1 & Malaysia \\
\hline & 4. PT.Derawan & 1 & China, Ukraina \\
\hline 4 Wakatobi & 1. WakatobiResort & 8 & $\begin{array}{l}\text { Sriss, Spanyol, Jepang: } \\
\text { Italia, USA, Inggris }\end{array}$ \\
\hline 5 Konvt & 1. PT.Komtara Sejati & 5 & China \\
\hline 6 Bombana & 1. PT. Surya Saga Utama & 110 & China, Ukraina \\
\hline \multirow[t]{4}{*}{\begin{tabular}{|l|l|}
7 & Konsel \\
\end{tabular}} & 1 PT. Jian Liang & 9 & China \\
\hline & $\begin{array}{l}\text { 2. PT. China Ganso Intemational } \\
\text { Construction }\end{array}$ & 28 & China \\
\hline & 3. PT.Ifishdeco & 6 & China \\
\hline & 4. PT. Sungai Raya Alloy Nickel Indonesia & 12 & China \\
\hline \multicolumn{2}{|c|}{\begin{tabular}{|r|} 
Jumlah \\
\end{tabular}} & \multicolumn{2}{|r|}{1045} \\
\hline \multicolumn{4}{|c|}{ 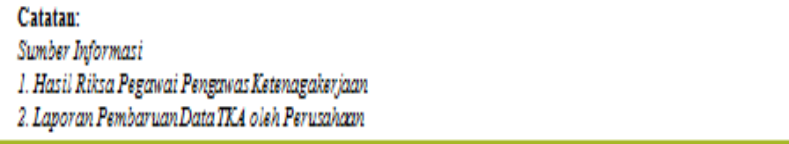 } \\
\hline
\end{tabular}

The above data shows that number of workers in informal sector (companies) is 91.201 persons from this number an amount of 1.045 persons are migrant workers. In other 
words, the percentage or migrant workers is $1.15 \%$ of total workers. Number of registered companies based on Law number 7 of 1981 is 7.238 companies. Among those companies 14 of it hires migrant workers or $0,19 \%$ out of the total number. The migrant workers in southeast Sulawesi works in tourism/ hospitality sector 9 person, fisheries sector 5 person and mining sector 1.031 person.

Based on interview with number of workers in a company which hiring migrant workers ${ }^{13}$ concerning the on going supervision system involving entire government element namely immigration office class I of Kendari city, labor and transmigration office and local police department. Most officers stated that there is lack of coordination and strict action lead to the remaining number legal violation either against administrative, civil and criminal law committed by migrant worker toward local citizen or workers.

\section{Immigration supervision toward violation of visiting visa by migrant worker in southeast Sulawesi}

In term of foreigner's supervision entering the territory of Indonesia particularly southeast Sulawesi, administratively done by checking the validity of immigration permit documents in the form of visa including visiting visa. Other action can be taken is data restrain and forbidden meant to prevent legal violation by ancipating foreigner's visa missuse.

Principally the selective policy means that only foreigners who benefitable for public welfare, state and country of Republic of Indonesia and disharm National order and safety allowed to enter the territory of the Republic of Indonesia. Therefore, objective of foreigners' supervision is to support safety and stability from outsider, provide safety and orderliness for Indonesia citizen dan foreigner and preserve the "safe" image in global stage and to preserve legal supremacy. Generally, there are several immigration supervision types, namely:

1. Close supervision, the supervision conducted without applying office attribute

2. Periodic observation

3. Trailed after target

4. Undercover

5. Field check to prove the sponsor legality

6. Intelligent, conducted based on public report, to search more sufiicient evidence

Intelligent operation is done without prior comfirmation to the hiring company, once the officer met foreigners' they will have document checking to be match with the

\footnotetext{
${ }^{13}$ Beberapa Pekerja di Perusahaan di Kota Kendari Provinsi Sulawesi Tenggara, wawancara dilakukan pada tanggal 20 Juni 2017.
} 
immigration officer's data. Further checking is visa checking, meant to find out visa suitability with their on going activities. If the visa and document are proven dismatch with their activities, the foreigner will evacuate to immigration office to be interrogated by enforcement officer for the purpose of case deepening. Afterward, in-depth checking is applied and written in an investigation report, once sufficient evidence is found, preliminary investigation will be applied to be continued to investigation stage.

According to Rusfian effendi ${ }^{14}$ as the migrant worker proven committed violation, immigration enforcement will be taken. There are 2 kinds of immigration enforcement namely immigration administrative and prostitia (court proceeding). Administrative action divided into various action, one of it is deportation, from January to April at least 20 foreigners being deportated to their home country.

As document checking resulting suitability, the foreigners may continue their activities. However if it unsuitable, they will be brought by immigration officer to have an investigation report. During 2017 several violations was found particularly administrative and criminal offense. Some visiting visa violations by migrant worker in southeast Sulawesi are:

1. Visiting visa violation by 6 (six) citizen of China. They identified as: Chen Yulin, Zhou Lifen, Liu Yunping, Haung Qinshui, Shen Xinbao dan Li Xinglie. The supervision and enforcement team of immigration office class I of Kendari city deportated them, however they continued mining location measurement activity in Morombo village, Langgikima district, south Konawe region which proven against immigration Law. Based on interview with Agus Setyadi, the office has conducted further investigation and the foreigners has arrested. Their arrival were sponsored by PT Hamjun, one of Chinese company, eventhougt it is a legal sponsor, however they used visiting visa for working which against the Law. He further explain that his office continuesly conducts supervision on foreigners who violates immigration Law Article 122 concerning permit and travel document missuse, as they will be deportated via Haluoleo airport and escorted until their home country.

2. Immigration case being administratively processed was 3 (three) Chinese foreigners, identified as Wang Chao, Zhou Hui and Luo Wenshui. They considered distracted national sovereignty and against immigration Law, their activites, land measurement and smelter construction in Konawe region southeast Sulawesi, after an investigation known used expired living permit. During their

${ }^{14}$ Kepala Sub Seksi Penindakan (Wasdakim) Imigrasi Kelas I Kendari, wawancara dilakukan pada tanggal 23 Juni 2017. 
activities, those foreigners hired a house in Landipo village, Moramo district, south Konawe region. The rescue applied based on joint intelligent operation between immigration office class I of Kendari city, labor and transmigration office of southeast Sulawesi, National Army's Strategic intelligent body (BAIS) and local army intelligent unit. Besides rescuing the Chinese migrant, officer also rescuing GPS device belong to those foreigners.

After a serie of investigation by immigration officer, those foreigners proven against Article 122, point (a) Law number 6 of 2011 concerning Immigration. Those three migrant workers were carried for final investigation and deportated to their home country. Their sponsor PT Siomay which located in Jakarta also pleads committed activities against given living permit namely doing land measurement for smelter construction.

According to an interview with Haerul Ikrar Rusli, obstacles of supervision on foreigners living permit includes:

1. Imbalance of number of officer with number of migrant worker, as there are only 3 supervision officers and 1 unit leader. This number is inequal to the number of migrant worker that keep increasing. The officers in charge to supervise thousands migrant worker accros authorized territory of immigration office class I of Kendari city, that is consist of 7 regions and 1city. Supervising foreigners in that area by 4 personel seems to be an overload task. Therefore, the above issue needs to overcome in order to increase supervision function of the local immigration office.

2. Lack of public participation to follow up visiting visa missuse conducted by migrant worker. Public participation is an important element to increase supervision function. As one of the stakeholder, public is a part o $\mathrm{f}$ supervision system toward illegal foreigner among the society. Public participation is needed to track the foreigner's activities. However, in fact public is care less with the existence of those foreigners.

3. Lack of government's human resources to conduct the supervision of migrant worker. This fact do not meet the immigration supervision concept which supposed to be conducted active and passively. As there are only 4 (four) personel which logically imposible to supervise the activities of 037 foreigners' across authorized area of immigration office class I of Kendari city. Moreover, the operational standard requires immigration officer to work in team it means they have tostay together. Such situation led to an ineffective supervision function. 
Therefore, passive supervision is needed, by responding public's report toward migrant worker who indicates violates immigration regulations.

Quantitavely, the supervision human resources strongly influences supervision implementation by immigration office class I of Kendari city, since this situation caused many companies are missed. It raised the potential of harmful foreigners and companies by misusing their living permit. Number of supervision officer are bellow miminum requirement as it inequal with the number of supervised companies that is around 13 companies. Particularly those companies located in remote and unaccessable area, as mining companies which located in the jungle and mountaneous area, causing the immigration office hardly implement their tasks and plan.

The respondent further described that the actual number of supervision officer only 3 personel, while we have to work in a tean and distances supervision objects location madeour tasks more difficult to implement. According to interview with Rofikoh Yunianto, it is known that the office has never proceed a report or directly handled visa missuse case whether in invterogation or investigation stage.

Thus, lack ofhuman resource caused the weakness of supervision function implementation which is a task of the immigration office class I of Kendari city. Thereby, maximum supervison toward companies hiring foreign labor in enable to accomplish. It requires an addition of human resources in order to fulfill a sufficient supervision.

\section{CONCLUSION}

1. Immigration supervision system on foreigners' living permit conducted by immigration office class I of Kendari city consist of two supervision types namely administration and in field supervision. Administration supervision conducted by checking the validity of immigration document which in the form travel permit or sponsor and visiting permit. Whereas infield supervision conducted by direct checking to each company whose hiring foreigner worker and monitored each sponsor or company reagarding their staying permit legal period.

2. Immigration supervision toward visiting visa missuse in the southeast Sulawesi can be done by preventing prior the legal violation is committed. Such prevention is applied by conducting periodic observation, undercover and taking intelligent action. Enforcement action is done by investigating, proceeding and deportating the foreigner. 


\section{Acknowledgments}

1. Every government elements who involved in supervision and enforcement tasks are expected to increace their coordination and be more strict in sanction sentencing any foreigner who against the Law.

2. The number human resources need to be increase (supervision officer) and it has to involve every related elemnts including public. In order to realize an effective and efficient supervision system.

\section{BIBLIOGRAPHY}

\section{Books}

Dewansyah, B. (2015), 'Perkembangan Politik Hukum dan Kebutuhan Hukum Keimigrasian Indonesia: Menjawab Sebagian, Melupakan Selebihnya', Hasanuddin Law Review, vol. 1, no.2.

Hamidi, J. \& Chritian C. (2015), Hukum Keimigrasian, Jakarta: Sinar Grafika.

Hasan, A. (2015), 'Pengawasan Dan Penindakan Keimigrasian bagi orang asing Yang melebihi batas waktu izin tinggal di Indonesia', Jurnal Hukum Lex et Societatis, vol. 1, no.1.

Indra, M. (2008), Perspektif Penegakan Hukum dalam Sistem Hukum Keimigrasian Indonesia, Disertasi, Program Doktor Pasca Sarjana Universitas Padjadjaran, Bandung.

Pudyatmoko, Y. S. (2009), Problem dan Upaya Pembenahan, Jakarta:Grasindo.

Sihombing, S. (2013), Hukum Keimigrasian, Bandung:Nuansa Aulia.

Soemitro, R. H. (2010), Dalam bukunya Mukti Fajar dan Yulianto Achmad. Dualisme penelitian hukum (normative dan Empiris), Yogyakarta: Pustaka Pelajar.

Sutanto, H. (2017), 'Penegakan Peraturan Keimigasian Dalam Mencegah Masuknya Imigran Illegal ke Indonesia', Jurnal Revormasi Hukum, vol. 1, no.1.

Tumpa, H. A. (2015), 'Penerapan Konsep Rechtsvinding dan Rechtsschepping oleh Hakim dalam Memutus Suatu Perkara', Hasanuddin Law Review, vol. 1, no.2. 